\title{
Civil Rhetoric for the Social State: On Gerd van Istendael's Precarius
}

Jakub Jinek

The recent publication of the Czech translation of Gerd van Istendael's essay The Parish of St. Precarius, ${ }^{1}$ accompanied by two commentaries written by myself and my two colleagues J. Šrajer and R. Míčka, ${ }^{2}$ has been received with a - rather unexpected - degree of vivid interest. The strong feedback on the essay and commentaries, both positive and negative, I received, and two subsequent discussions on the volume the author had with Czech students made me think that the topic of precariate is still retaining its resonance. Therefore I gladly accepted the initiative to publish an English version of my commentary with the hope that our discussions on Van Istendael's text could be of some interest for the international audience too.

In the new version, the latter part of the original text in Czech is left out, whose major portion was a rather long survey of foreign literature, summarizing for Czech readers the discussions of the notion of the state conducted in the West over the last few decades. The main systematic point I made against the background of that discussion was that the social state is a manifestation of some ethical values that, historically, have their origin in the state itself. I wish to develop it on a greater scale at another opportunity. Here I confine myself to discussing Van Istendael's position with two main goals: on the one hand, I intend to advocate Van Istendael's intuition that the social state is a product of European high culture and civilisation and defend his position from being ranked as Marxist; on the other hand, I want to show - rather briefly - that the way of reasoning it proposes also has intrinsic limits given by its restricted perspective. $^{3}$

An examination of Van Istendael's essay ought to begin with a reflection on the metaphor of St Precarius present in its very title. The English expression 'precarity' is derived from 'precarious', which means uncertain or unstable. It describes the situation of people who are dependent on occasional and inadequately paid work which excludes the possibility of a decent standard of living and which is, above all, legally unprotected. ${ }^{4}$ In the last few decades, increasing numbers of especially young people from the lower and middle classes are trapped in this situation. The unemployment or partial-employment of millions of young people in some European states (especially on the European periphery, i.e., in Spain, Portugal, Italy, Greece and Poland) is generally recognised as a great social danger. Although its reality is difficult to doubt, its causes can be disputed.

The expression 'precariate' has been implemented and used with such polemical intention since the early 2000s, ${ }^{5}$ forming the foundation to which the metaphor of St Precarius is linked.

1 G. van Istendael, Farnost sv. Prekéra, Praha (NLN) 2014.

2 J. Jinek, Sociální státnost a státní etika (Social Statehood and State Ethics); J. Šrajer - R. Míčka, Farnost sv. Prekéra a pohled sociálního učení církve (The Parish of St. Precarius and the View of the Social Teaching of the Church), both in: G. van Istendael, Farnost sv. Prekéra.

3 In the present version of the text I made some minor corrections in bibliography and reasoning. I am indebted to Lucie Kolářová, the translator of Van Istendael's essay into Czech, for help with references to the Dutch edition of the essay.

4 In an attempt to capture the context of the term more closely, one can speak about a situation of labour-law insecurity and resulting social insecurity. Rychetník uses the Czech equivalent for 'uncertain work'. L. Rychetník, Sociální spravedlnost: jak jí rozumět dnes?, in: Sociální práce/ Sociálna práca, 14, 2014, p. 16.

5 See U. Brinkmann - K. Dörre - S. Röbenack - K. Kraemer - F. Seidel, Prekäre Arbeit. Ursachen, Ausmaß, soziale Folgen und subjektive Verarbeitungsformen unsicherer Beschäftigungsverhältnisse, Bonn 2006; R. Castel - K. Dörre (ed.), Prekarität, Abstieg, Ausgrenzung. Die soziale Frage am Beginn des 21. Jahrhunderts. Campus, Frankfurt a. M. - New York 2009; G. Standing, The Precariat: The New Dangerous Class, London - New 
It describes the thus afflicted mass of people, while not denying similarity to the expression 'proletariat'. This allusion refers to critical theory concentrating on the structure of inner disruption of the capitalist system. In light of this, the polemical irony of the religious metaphor reveals itself. The Latin expression precarius means 'obtained by begging, praying, imploring; given out of mercy'. In Roman law, the institution of precarium is known, referring to rendering the usage of an item to someone else on condition that it can be demanded back at any time. With this additional nuance the expression 'precariate' gains a more succinct meaning when it is applied to the contemporary economic-social situation. People find themselves in a precarious situation when they are highly grateful to their employers for unstable work. Thus we can call these people precarists, with the employers taking the part of merciful givers. In the sociological approach the precarists constitute a border phenomenon: these people are on the verge of poverty, though they are not destitute. This border phenomenon is specific for the life condition of the precarist's dependence on the goodwill of others, i.e., employers and benefactors, to whom he is totally grateful. The precariate differs from the peculiar freedom of those in destitution. The precarist is bound by gratefulness, which leads to two consequences: First, the precarists are paralysed in any effort to improve their situation, because they do not understand their work as their market value in the sense of classic economic theory, but perceive it as a received gift. Second, their situation arouses the motivation to protect their gift from others of the same status who are, however, less fortunate in lacking the gift. Thus, the group's social unity, which might have enabled engendering shared action, is undermined. ${ }^{6}$ Hence, the precariate is a disunited and diffused group; ${ }^{7}$ that is why one cannot talk about a class in the classical sense.

The social dynamics which in the $19^{\text {th }}$ century created the working-class movement and enabled the collective enforcement of the right of work against the interests of capital is today absorbed by keeping the mass of workers in a grateful position. The suggested comparison with those in destitution, beggars and the homeless is very instructive here. For in case of the precarists, the Marxist saying "they have nothing to lose but their shackles" ${ }^{8}$ does not hold true. Thus, according to the critics, the social phenomenon of 'precariate' is a conscious tool of socio-economic mass manipulation which is non-violent, yet all the more effective; ${ }^{9}$ this, however, is the most polemical part of the theory. Nevertheless, capital succeeded in achieving what it failed to do in the $19^{\text {th }}$ century due to resistance of organised workers. Additionally, this was achieved without the state's coercive power through the clever combination of 'sugar and whip', i.e., by combining offered consumption possibilities (linked to a strong support of hedonistic consumerism in the form of advertising and entertainment industry, loans and technological innovation of communications) on the one hand with reduction of the state's social services and offer of solely precarious work on the other.

It must be noted that the most polemical part of the theory is at the same time the most difficult to prove, as it pertains to the troublesome question whether the elites bear some collective self-awareness, intentionality and a unified strategy. ${ }^{10}$ Undoubtedly, different answers to this

\footnotetext{
York 2011. However, the theory of precariate had been developed previously: P. Bourdieu, The Logic of Practice, Cambridge 1990; R. Castel, Les métamorphoses de la question sociale, une chronique du salariat, Paris 1995; M. Hardt - A. Negri, Empire, Cambridge (Mass.) 2000.

6 In this context one can mention the sociological analyses of the hostility of the middle classes which is directed exclusively onto the lower classes. See J. Keller, Tři sociální světy, Praha 2010, pp. 141-142.

7 For a sociological overview of groups belonging to the precariate see G. Standing, The Precariat, pp. 13-16.

8 K. Marx - B. Engels, Manifest komunistické strany, Praha 1972, p. 43.

9 Cf. G. Standing, The Precariat, pp. 26-58, 132-154.

10 See R. Michels, Zur Soziologie des Parteiwesens in der modernen Demokratie. Untersuchungen über die oligarchischen Tendenzen der Gruppenlebens, Leipzig 1911, pp. 375-376, 381; my usage of the term "elite" in the following text is based on Michel's notion of "oligarchy": a social class which inevitably occurs as a consequence of complex social organisation and seeks to preserve its power (pp. 32, 351-382). Michel's analysis of
} 
fundamental question mark out the opposing positions in the principal socio-scientific argument. It can be assumed that if the critics' interpretation of 'precariate' is generally accepted, this would entail consequences laid upon the current socio-economic order. So, as long as the general uncertainty concerns the cause of the problems of those in destitution, i.e., whether by the conditions, by the time of crisis, or by personal/group failure (cf. the problems of increasing nationalism and xenophobia), social dynamics will be used up by these non-system questions and problems.

This critical point is the precise place where Van Istendael enters the indicated polemics with his essay. Its title does not leave any doubts about the author's approach to this problem. Van Istendael adopted the motif of St Precarius created by young activists at the May Day celebration in Milan in 2004, long before the outbreak of the financial crisis; the May Day celebration was renewed in a new spirit already in 2001. The gathered participants thus expressed their generation's feeling of being pushed into the role of supplicants who depend on getting a job at any costs and without a long-term prospect. However, this was not a sudden, spontaneous outbreak of collective frustration. The roots of the 'San Precario' movement reach back to the anti-globalisation protests organised in the 1990s. Van Istendael stresses precisely this time specification. He points to the fact that the 'precariate' is a system phenomenon, rather than a problem linked to a specific situation within an economic crisis. The crisis was only used as an opportunity for global markets to intensify the current pressure on change of work relations. The effect of unemployment increased the precarity, and therefore also the effectivity of imploring, and higher pressure lead to a further profit increase of the rich at the precariate's expense. The fact that during a crisis the rich do not grow poorer as others do, but rather verifiably continue to grow richer, increases the suspicion of crafty planning. "It almost seems as if the whole economic and financial crisis was just one big pretext for destroying the social system," Van Istendael summarises this suspicion. ${ }^{11}$ Among the suspects he counts European commissions with European institutions in general, as their attempt to save the crisis economies resulted, due to the inflation caused, in a disadvantage to the non-privileged ones.

Although Van Istendael does not draw any conclusions from these facts, we will surely not miss the gist of his text if we interpret it as an affirmation of the key point of the globalisation critics: the combination of market activities and European institutions with their concentrated pressure suggests that they are deliberate and intentional. One must not omit the fact that Van Istendael enters the debate on the activists' side as an involved journalist, rather than a describing and value-neutral scholar. Also, his choice of St Precarius as the key motif must be taken into account, symbolising the civil-activist rather than the academic-sociological part of the precariate theory supporters. ${ }^{12}$ Van Istendael's father was an important representative of Christian social teaching and also a lay participant at the Second Vatican Council; although his son, our author, does not directly identify with social teaching of the Church, his interest in the spiritual dimension of the social question is apparent.

Naturally, objections will arise against the conclusion according to which the precariate is primarily a result of focused market and political pressure. The most serious is voiced from the pluralistic theory position. One cannot speak about the unified selfish activities of the elite in an intrinsically complex society, where the society's direction is determined by the intentions and actions of an innumerable amount of individual and collective players at any given moment;

the socio-psychological rules of the masses' gratefulness to their superiors is notable with regard to the theory of the precariate; see pp. 60-62. 11 G. v. Istendael, De parochie van Sint-Precarius, Amsterdam 2013, p. 20.

12 For this distinction, see U. Brinkmann - K. Dörre - S. Röbenack - K. Kraemer - F. Seidel, Prekäre Arbeit, p. 8. 


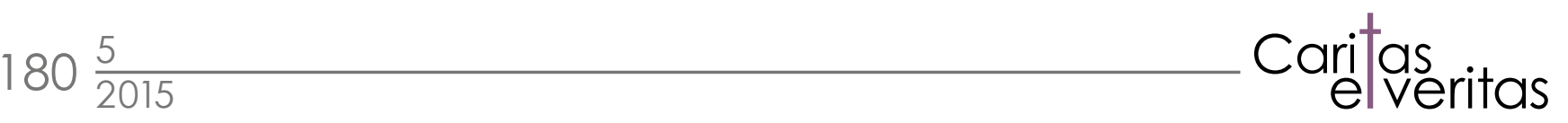

their autonomous and frequently opposing actions create, to a certain extent, a pluralistic society where the government's role is rather that of a mediator regarding various interests. ${ }^{13}$ To claim otherwise means to ignore the basic facts about the character of modern society, and slip into naïve and schizophrenic ideas about conspiracy of the powerful.

However, Van Istendael is far from developing theories about conspiracy, backstage agreements and secret brotherhoods. He interpreted the focused pressure against the precariate in a different way. According to him, this pressure is lead by a form of economic rationality which focuses solely on individual profit to the detriment of others, in a sense a zero-sum game. Although the author did not state this explicitly, he probably means the following: if the actions and attitudes of bankers, financiers and European politicians are governed by a single rationality, it is possible to talk about a unified intention of their actions. Of course, this rationality is fallen and therefore the unity in question among the dominant players is rather accidental, almost chaotic, however strongly it is focused, with a kind of an intrinsic need, against other groups' interests. The deficiency of this rationality is manifested by its intrinsic contradiction. At its core is the theory about the invisible hand of the market (according to Van Istendael "a superstition from a "wig era'"14) which contains the idea of some specific necessary succession of social phenomena, which, as a social agent, is characterised by irrationality, same as any necessity. Thus the rationality of the markets is based on a deeply irrational theory.

The author contrasts this fallen rationality with another, seemingly banal and commonplace rationality of modest middle class requirements (such as a house with a front garden, family and reasonably paid work). However, this rationality is shown as legitimate and finds its expression in democracy and social statehood, which for Van Istendael are great artefacts of the European civilisation just like cathedrals and symphonies. Thus, according to his commentary, the perverted rationality of global markets and European institutions becomes at the same time an enemy of European civilisation. Its supporters act as barbarians attacking the gentle and peaceful inhabitants of a cultural civitas. The pointed image of Attila ante portas best captures Van Istendael's developed thought.

Using the contrast between civilised rationality and barbarian irrationality, the author succeeded to avoid the indicated suspicion of constructing a conspiracy theory. It also enabled him to transform the old sociological analysis of modern society as divided into actively planning elites and passively controlled masses ${ }^{15}$ into a more lively and impressive image. As much as the author agrees with the classical sociological theory in the key polemical point, in the possibility of understanding the elite as possessing a unified identity and intention, he completely differs in evaluating the opposite side, ascribing a rational identity to the non-privileged majority as well. This is not done in a Communist Manifesto style showing the seemingly dominant and manipulating elite as already doomed to downfall while the oppressed would be the true ally of history. Van Istendael's text, although a manifesto of a kind, does not build on some historically necessary class contrast. The precariate's rationality is not to lead to a united action against the opposing class. After all, according to the author's own analysis, the case of the majority is about individual, and thus restricted (however legitimate), interests. So Van Istendael offers a constructive program rather than class action: particular legitimate rationalities find their unifying point in the idea of social statehood built on solidarity.

13 R. A. Dahl, Who Governs: Democracy and Power in an American City, New Haven 1961.

14 G. v. Istendael, De parochie van Sint-Precarius, p. 40.

15 See footnote 10. 
Van Istendael's specific suggestions for a solution should be read in light of this program of unifying rationality. The aim is to suppress the irrational rationality, especially by restricting irresponsible speculations at the financial and commodity markets, by forgiving debts, 'exporting' social statehood outside Europe (probably intended against the irrationality of globalisation) and also restricting management rewards. All these tools ${ }^{16}$ are conceivable only if accompanied by the prerequisite of enforcing true rationality. This presupposes two things, if I understand the author correctly. First, there is a need for the people involved to recognise the character of the present situation and to be willing to act accordingly. In this context the author claims that "[t]he markets are not a natural phenomenon. The markets are the work of man" ${ }^{17}$ So any change first requires overcoming the idea of the necessary effect of the market's invisible hand; the motivation of Van Istendael's paper is to lead the reader to the same view about rationality and irrationality. The other condition for enforcing civil rationality is, for a variety of particular interests, the state and more precisely the welfare state as the sole warrant.

It is thus becoming apparent that Van Istendael's essay was not lead by a polemical idea, a fatalistic or historically descriptive model of two competing classes. The suggested opposition of civilisation and barbarism should not call for (violent) action, prompting the Romans to destroy Attila's army. The contrast between the precariate and the financial markets was presented only in order to be overcome. The point was to offer an analysis which would not only bring the non-privileged to see the situation but also to persuade the privileged about the situation's irrationality. As such, we can rank it as a piece of civic rhetoric.

The privileged person should face the decision to choose his side of the civilisation's conflict as described. For this it is not necessary to attribute contemptible interests to him. The point here is not to inspect the financier's intrinsic intention, the politician's moral value or the person's general attitudes; it is rather to offer more positively and non-moralistically a model which would prompt adopting an active civic position. So potential conflicts which are real and direct can arise precisely from facing an evident alternative; the precarist's enemy is not the one who works in the financial sector but the one who, sufficiently informed, disagrees on the civilisation theory and regards the current state of affairs as legitimate. Clearly, the author assumes that any reasonable being, having the truth of the situation as shown, must decide for civilisation and against barbarism.

This reasoning could readily resemble some Kantian ideas; however, it remains rather undeveloped in an important aspect. The contrast between barbarism and civilisation depends not on a theoretical justification of social statehood itself but rather on empirical evidence of obvious empirical facts. As I have already mentioned, what Van Istendael intends and what we can expect of him is not rigorous scholarship seeking sound evidence, but civic rhetoric whose goal is persuasion. However, it is clear that the rhetoric of obvious empirical facts finds itself in a "precarious" situation, since the facts it depends on could be constantly disputed and easily replaced by other empirical evidence. This is, after all, why the thesis that social statehood is a manifestation of civilisation, which is at the core of Van Istendael's essay, is the scene for fundamental social conflict.

Van Istendael's essay thus stands or falls with whether we are convinced of a specific empirical perspective on the situation. If we accept the theory about the unity of the elite's actions

16 On a more specific level, Istendael suggests prohibiting high frequency trading, prohibiting or restricting banking investment activities, creating emergency funds from private resources rather than public ones, regulating the derivatives market and taxing speculative investments. 17 G. v. Istendael, De parochie van Sint-Precarius, p. 36. 
and the irrationality of their attitude, then we are highly unlikely to hesitate supporting the program suggested by Van Istendael. However, I am afraid that this result is far from certain. The possibility of bringing in a quite different set of various facts remains open, especially in other than Western European context. For an illustration of my doubts I want to mention what I see as a three-fold empirical obstacle for a Czech reader to accept Van Istendael's thesis and program. The first one reflects a different impact of globalisation on Eastern Europe. At least in the beginning the Czechs appeared not to be the afflicted but the winners. Today we suspect that the transfer of many companies from the West here brought only a Pyrrhic victory, because importing hundreds of thousands of square metres of logistics and the simplest factory workshops brought with it so many negative externals and socio-ecological debts that in the end these prevail over all economic advantages. Nevertheless, the Czechs have not undergone the socio-psychological shock caused in Western Europe by an extensive one-way company exodus. The second reason is related to this: the mass industrial restructuring of the 1990s, which affected some regions' employment rates and social structure at least as drastically as the companies' flight in the West, was not understood as part of globalisation but as punishment for doing sweet-nothing during 'real socialism'. Today we are somewhat wiser in understanding that some bankruptcies were not at all necessary, and also in recognising the existence of a strong interconnection between the shutdown of domestic companies and worldwide economic movements. However, an obstacle to accepting the precariate's perspective here is the differing emotional impact of processes which are very similar in reality. This brings us to the third reason, perhaps the most important one. Behind Van Istendael's description of detrimental changes in the Western economic and social structure within recent generations one can notice appeal to the shared experience of the privileged post-war generations who lived in Western Europe in peace, prosperity, and with social security. Today this refers to the typical rich Western pensioners who are a kind of a remaining stratum of the former society, an old reminiscence of the golden age. It is possible to identify with such nostalgia inter-generationally (for example, this is illustratively demonstrated by Michael Moore in his famous film Capitalism: A Love Story); however, it proves more difficult from the perspective of the other end of the continent. ${ }^{18}$

Though I am convinced that the Eastern European perspective does not necessarily act as gravedigger for the theory presented and that the Czech approach to global problems expresses cultural relativism rather than a legitimate alternative as such, ${ }^{19}$ the presented facts, in my opinion, clearly show that the rhetoric of empirical sociological and economic facts and emotional reminiscences had to be systematically strengthened. One would have to return to the social statehood theory and seek justification that can be accepted by any reader regardless of her origin and experience. That Van Istendael does not take up this task can only partly be explained by the difference of genre. The problem is more fundamental and has to do with our author's theoretical assumptions which - without being explicitly stated - govern his whole discussion and limit the possibility that the offered analysis will be widely accepted and thus result in a political change.

Van Istendael's general political outlook could be described as moral and civic. The author tries to restore and legitimate the social state by an appeal to conscious citizenship and social intersubjectivity of citizens. We find no call for a change in power relations, no claims to rule

18 The same topos of nostalgic reminiscence is also used by another famous globalisation critic: T. Judt, Ill Fares the Land, London, etc. 2011, pp. 41-80; similarly R. E. Goodin, The end of the Welfare State?, in: T. Ball - R. Bellamy (ed.), The Cambridge History of Twentieth-Century Political Thought, Cambridge 2008, p. 202.

19 However, this changes nothing about that fact that if authors like Istendael, Judt and Moore intend to persuade all reasonable people, rather than merely those who share the same life-experience, to adopt a form of such appeal, they are committing, at least, a tactical error. 
for particular group, no ascribing of individual mistakes, no judgements about right or wrong beliefs and characters, no reference to good or bad way of life. Van Istendael's approach to political problems obviously formal in character - its Kantian inspiration has already been indicated. However, the problem of the precariate concerns the material state of modern societies; Van Istendael's pleas for a justifiable, decent degree of material security for the middle classes admit this after all. The question that arises, then, is the following: is Van Istendael's civic rhetoric to be conceived really as a deliberately chosen strategy, or is it rather the only way he can address his fellow citizens under the adopted formal assumptions?

Much has been written about the inability of formal Kantian theories to contribute to real political issues having to do with the distribution of material goods. Though some attempts in this field have recently been made (the most influential being surely the justice theory of J. Rawls), the fundamental methodological problem could not be eliminated: In addressing the problem of property distribution one cannot ignore the ethical contents of our societies' organisation. In this very sense, any advocacy of the social state as a European cultural value not only must include an exposition of such values as solidarity, rationality, civilisation and culture; as values, these must also be related to the question of the common good. ${ }^{20}$ But this perspective which inevitably opens the question of the proper structure of society, of its appropriate functioning, and indeed also of the malfunctioning of its elements and individual members, calls, as a consequence, for a much more radical criticism of global capitalism than that presented in Van Istendael's essay. Though on one hand, as we have seen, the universalism construed on civic and moral background saves our author from a Marxist-like, polemical kind of thinking; on the other hand, it does not allow for identifying and ascribing the concrete errors and misdoings. Facing the perversion of contemporary speculative capitalism, the civic rhetoric of universal citizenship can only form a part of the attitude of the responsible intellectual; the other is the search for substantial justice which includes both its metaphysical grounding in the Good and its concrete application in the individual soul and in (the structures of) the modern state. ${ }^{21}$

\section{Civic Rhetoric for the Social State: On Gerd van Istendael's Precarius}

Abstract The paper discusses the concept of the precariate as it occurs in Gerd van Istendael's essay The Perish of St Precarius. The goal of the paper is, on one hand, to show that Van Istendael's usage of the concept is a piece of civic rhetoric rather than of ideology of Marxist type; on the other hand, that this approach has its inner limits given firstly by a limited perspective and secondly by neglecting the core question of common good.

Keywords precariate, social justice, state, social security, civic rhetoric, common good

20 For this point, see L. Rychetník, Sociální spravedlnost: jak jí rozumět dnes?, p. 14.

21 The paper was supported by the grant of Charles University in Prague (VVZ No. P13 "Proměny etiky"). 